\title{
Quality of life and related factors among older people living in rural areas in south-eastern Poland
}

\author{
Agnieszka Beata Ćwirlej-Sozańska, A-F, Bernard Sozański², ${ }^{2, E-F}$, Agnieszka Wiśniowska-Szurlej ${ }^{1, C-F}$, \\ Anna Wilmowska-Pietruszyńska ${ }^{1, A, E-F}$ \\ 1 Institute of Physiotherapy, Medical Faculty, University of Rzeszow, Rzeszow, Poland \\ ${ }^{2}$ Centre for Innovative Research in Medical and Natural Sciences, University of Rzeszow, Rzeszow, Poland \\ A - Research concept and design, B - Collection and/or assembly of data, C - Data analysis and interpretation, \\ $D$ - Writing the article, E - Critical revision of the article, F - Final approval of article
}

Ćwirlej-Sozańska AB, Sozański B, Wiśniowska-Szurlej A, Wilmowska-Pietruszyńska A. Quality of life and related factors among older people living in rural areas in south-eastern Poland. Ann Agric Environ Med. 2018; 25(3): 539-545. doi: 10.26444/aaem/93847

\begin{abstract}
Introduction. Quality of life (QOL) is an important aspect of life, reflecting health and conditioning the well-being of older adults. Maintaining the QOL is essential in times of demographic changes which resulting longer life spans, and consequently an increased proportion of older adults in society.

Objective. The aim of the study was to assess the quality of life and its basic determining factors in the elderly living in rural areas of south-eastern Poland.

Material and method. The study was conducted on 973 respondents aged $60-80$ years living in rural areas of south-eastern Poland (Podkarpackie Region). The research tool used in the study was the WHOQOL-Bref and a questionnaire on personal characteristics and health. Statistical analysis was performed using Statistica version 10.

Results. All quality of life domains assessed were above the median values of the scale. The highest values were found in the social domain $(67.35 \pm 17.31)$ and the lowest values in the physical domain $(58.74 \pm 14.80)$. All the quality of life values decreased with an increase in age and increase in number of chronic diseases in a given person. A higher quality of life was found in subjects who were physically and socially active.

Conclusion. The study stresses the impact of modifiable determiners of QOL. Interventions aimed at improving the quality of life of older adults should involve interdisciplinary monitoring of health, early treatment of diagnosed problems, and promotion of physical activity and daily life activities.
\end{abstract}

\section{Key words}

aged, QOL, health status, rural population, linear models

\section{INTRODUCTION}

The quality of life (QOL) of older adults is an important aspect of their lives, reflecting their health and conditioning their well-being. Good QOL of the elderly means that they function well in their environment, and its maintenance is essential in times of demographic changes resulting in longer life spans, and an increased proportion of older adults in society [1].

The increase in the number of chronic diseases that accompanies older age [2], as well as numerous environmental factors affecting the life of aging individuals [3], significantly impact on their QOL [4]. Low QOL is reciprocally related to poorer health and decreased functioning of older adults [5].

Nowadays, the QOL of older adults is believed to be essential, the improvement of which becomes one of the key aims in the domain of public health. Studies conducted to assess QQL among aging individuals have found that older age, gender, poor subjective health, depression, dependence and rural life [6], education and economic status [7], as well as chronic diseases [8], constitute a group of factors that negatively affect the QOL of older adults in several

Address for correspondence: Agnieszka Beata Ćwirlej-Sozańska, Uniwersytet Rzeszowski, Warszawska 26 A, 35-205 Rzeszów, Poland

e-mail: sozanska@ur.edu.pl

Received: 15.05.2018; accepted: 31.07.2018; first published: 18.09.2018 countries. Measuring QOL values among older adults and determining its associated factors have significant importance for introducing preventive interventions among older adults in a given region [4].

Quality of life of older adults from rural areas needs to be put under scrutiny, as, objectively, their situation is more difficult because of housing conditions, income or accessibility of services. In rural areas older adults usually live in their own houses, often of low technical standard and insufficiently equipped. Individual households are usually scattered over vast areas, and their long distance from urban centres means that services are not easily accessible. The advantage of living in Polish rural areas are its inhabitants' attachment to tradition and the related fact that older adults benefit from the position of authority, accompanied by the readiness of people to provide help to their neighbours [9].

This study aimed at assessment of QOL and its essential determining factors in aging inhabitants of south-eastern Poland.

\section{MATERIALS AND METHOD}

The study was conducted on 973 respondents aged $60-80$ years living in rural areas of south-eastern Poland (Podkarpackie Region). The respondents were selected from a randomly 
chosen and analyzed group of 1,800 respondents. Data for the analysis was obtained from the database maintained by the Ministry of the Interior and Administration of Poland. A total of 31,029 respondents was drawn from the database. The base group for each age group was drawn, without replacement, and used the Statistical Package for the Social Sciences (SPPS) programme, version 23. The chosen sample is representative for the studied region.

The study took place at the turn of 2015-2016. To obtain the necessary data, interviews we conducted with the respondents. The criteria for inclusion in the study population were: age between $60-80$ years, normal cognitive state (AMTS - abbreviated mental test score $>6$ points). The interviews were conducted by suitably trained pollsters in respondents' places of residence. In accordance with Declaration of Helsinki, the respondents were provided with information about the aim and the course of the study, and expressed their informed consent to participate. Approval to perform the study was obtained from the Bioethical Commission of the University of Rzeszów.

The research tools used in the study were the WHOQOLBref and a questionnaire on personal characteristics and health.

WHOQOL-Bref. The WHOQOL-Bref is a research tool measuring quality of life of a variety of respondents and populations. WHOQOL-Bref allows for assessment of quality of life in four domains: physical, psychological, social relations and environment. The answers to the questions were rated on a five-point scale that determines the level of difficulty or problem. The scale is oriented positively, which means that a higher number of points denotes a better quality of life (points 1-5).

The tool also contains two points analyzed separately that focus on individual overall perception of quality of one's life and individual perception of one's general health. The points for each domain are determined by calculating the arithmetic mean of each of the positions from individual domains. The calculated means have to be multiplied by four, so that the results are comparable with WHOQOL-100. The obtained results are assessed on a $0-100$ scale (where 0 denotes very poor quality of life, and 100 denotes very good quality of life) [10].

Another questionnaire was used to collect sociodemographic data. For the purposes of this analysis, the following variables were selected: age, gender, marital state, education, physical activity, physical exercise, social participation (understood as membership of an association or organization), and number of diagnosed chronic diseases.

Statistical analysis. The collected data was analyzed with the use of StatSoft, Inc. (2011) programme Statistica (data analysis software system) version 10. Preliminary analysis used the measurements of descriptive statistics. Due to lack of normal distribution of the assessed characteristics in individual subsamples, the non-parametric Mann-Whitney U test and Kruskal Wallis test we used. To assess the impact of quantitative sociodemographic variables on the quality of life, linear correlation coefficients ( $r$ ) were determined and their significance was examined by means of the significance test of the linear correlation coefficient. Linear regression models describing the quality of life in individual areas were estimated by means of WHOQOL depending on the combined impact of these sociodemographic variables, which had a statistically significant impact on these areas.. Statistical significance was set at $\mathrm{p}<0.05$.

\section{RESULTS}

Demographic characteristics of respondents. The study involved 973 respondents - 549 women and 424 men; mean age -69.6 years and mean number of diseases -4.73 . The majority of the sample were women $(56.42 \%)$ and the persons who were either married or lived in a partnership (68.65\%). Almost half of the respondents had primary or lower education (45.32\%). The majority of the respondents did not perform physical activity daily of a minimum of 150 minutes per week (68.55\%), and did not perform physical exercise (80.58\%). Most of the respondents did not belong to any social organization (60.45\%). All quality of life domains were assessed higher than the median of the scale. The highest values were found in the social domain $(67.35 \pm 17.31)$, while lowest in the physical domain $(58.74 \pm 14.80)$. The mean assessment of overall quality of life was $3.58( \pm 0.84)$, while the mean assessment for general health was 3.40 ( \pm 1.06$)$ (Tab. 1).

Bivariate analysis. In all the domains, the respondents' age and number of diseases, education, marital status and physical activity performed for a minimum of 150 minutes per week had a significant impact on the quality of life (QOL), and in satisfaction with overall quality of life (Q1) as well as satisfaction with general health (Q2). Respondents with poorer education, who were single, with low physical activity, older, and with a greater number of chronic diseases, had a significantly lower QOL. Additionally, performing physical exercises to strengthen muscles and improve physical performance had a significant impact on the QOL in the psychological, social relations and environment domains. Respondents who did not perform exercise had poorer QOL in these three domains significantly more often. Social activity, expressed by membership social organizations, groups or associations, had significant impact on the QOL in the psychological and environment domains. Older adults who did not participate in social activity, significantly more often had a poorer QOL. Gender had significant impact on QOL - women more often assessed their general health (Q2) and quality of life in the social domain as being poorer (Tab. 2).

Linear regression model. The model included the variables which differentiated the studied group in relation to having at least one problem related to any of the WHOQOL-Bref domains.

Quality of life in the physical domain lowered significantly with age and with increase in number of chronic diseases. QOL in the physical domain proved to be significantly higher in respondents who performed physical activity for at least 150 minutes per week. It was also significantly higher in respondents who were married or lived with a partner.

QOL in the psychological domain decreased significantly with age and with increase in number of chronic diseases. However, it was significantly higher in respondents who performed physical exercise four or more times a week, respondents who were socially active, and respondents who were married or lived with a partner. 
Table 1. Socio-demographic characteristics of the studied population

\begin{tabular}{lcc}
\hline Socio-demographic characteristics (N=973) & $\begin{array}{c}\text { Number }(\mathrm{N}) / \\
\text { Mean (SD) }\end{array}$ & $\begin{array}{c}\text { Percentage }(\%) / \\
95 \mathrm{Cl}\end{array}$ \\
\hline $\begin{array}{l}\text { 1. Gender } \\
\text { Female }\end{array}$ & 549 & 56.42 \\
Male & 424 & 43.58 \\
\hline 2. Age & $69.6(6.1)$ & $69.2-70.0$ \\
\hline 3. Marital status & & \\
In a relationship & 668 & 68.65 \\
Single & 305 & 31.35 \\
\hline 4. Education & & \\
Primary or lower & 441 & 45.32 \\
Vocational & 249 & 25.59 \\
Secondary & 206 & 21.18 \\
\hline Higher & 77 & 7.91 \\
\hline
\end{tabular}

5.Physical activity performed daily a minimum of 150 minutes per week

$\begin{array}{lll}\text { No } & 667 & 68.55 \\ \text { Yes } & 306 & 31.45\end{array}$

6. Physical exercises performed to strengthen muscles and improve physical performance per week

$\begin{array}{lcc}\text { No } & 784 & 80.58 \\ 1-3 \text { times } & 101 & 10.38 \\ 4 \text { and more times } & 88 & 9.04\end{array}$

7. Membership in at least one organization/ group/association (social activity)

\begin{tabular}{lcc} 
No & 774 & 79.55 \\
Yes & 199 & 20.45 \\
\hline 8. Number of chronic diseases & $4.73(3.50)$ & $4.51-4.95$ \\
\hline
\end{tabular}

9. WHOQOL-Bref domains

\begin{tabular}{lcc} 
Physical & $58.74(14.80)$ & $57.81-59.67$ \\
Psychological & $60.04(12.92)$ & $59.23-60.86$ \\
Social & $67.35(17.31)$ & $66.26-68.44$ \\
Environment & $63.87(16.76)$ & $62.82-64.93$ \\
Q1 - subjective overall quality of life & $3.58(0.84)$ & $3.52-3.63$ \\
Q2 - subjective general health & $3.40(1.06)$ & $3.33-3.47$ \\
\hline
\end{tabular}

In social relations, the QOL decreased with age and with increase in number of chronic diseases. It was higher in respondents who performed physical activity for at least 150 minutes per week and in respondents who were married or lived with a partner.

In the environment domain, age and number of chronic diseases also had significant impact on lowered QOL which, however, improved significantly in respondents who performed physical activity for at least 150 minutes per week, performed physical exercise four or more times a week, and in respondents who were married or had partners.

Subjective overall QOL and subjective general health decreased significantly with age and with the number of chronic diseases. They were higher in respondents who performed physical activity for at least 150 minutes per week and who were married or lived with a partner (Tab. 3).

\section{DISCUSSION}

The phenomenon of aging societies in European countries is a serious demographic, social and economic issue. The presented study shows that all means of domains of quality of life (QOL) of the aging inhabitants of south-eastern Poland were higher than the median. The social domain scored highest, and the physical domain scored lowest. The physical domain is one of the poorest assessed domains of the QOL of older adults $[11,12]$. Physical functioning deteriorates with age and impacts on the QOL and the physical ability to perform activities of daily life independently [13]. Quality of life of the elderly in Poland is higher than in other countries of Middle and Eastern Europe, i.e. in Serbia, Ukraine, Moldova and Montenegro [14]. In countries of Western Europe, the percentage of older adults with low QOL is much lower than in Poland [15]. According to the report Population Ageing in Europe, the citizens of former socialist countries assess their health lower and are less satisfied with life than citizens of European Union-15 [16]. The differences between the western and the eastern parts of Europe depend on several factors: socio-economic conditions, the development of free market economy and social services, as well as on social policies. This is why it is necessary to study and to understand the determinants of subjective well being, using comparable tools, in order to narrow the gap between countries.

Factors that most significantly resulted in lowered quality of life in all studied domains and in subjective general quality of life and overall health of the studied elderly living in rural areas of south-eastern Poland, were older age and number of chronic diseases. A factor that significantly improved the QOL in all studied domains, overall QOL and subjective general health, was being married or having a partner and performing physical activity daily a minimum of 150 minutes per week (except psychological domain). A significant factor for improving the QOL in the physical domain, social relations and environment, was performing physical activity four or more times a week. A significant factor in improving the QOL in the psychological domain was the social participation of older adults.

In the current study it was found that older age had a particularly strong effect on the decreased QOL of older adults. Lowering of the QOL with age was reported by other authors, too. Kumar et al., in their studies involving multiple linear regression analysis, found that older age $(\mathrm{p}=0.014)$ is related to a low score on the QOL [17]. In Poland, this decrease was particularly significant, as shown by an international study. Raggi et al. proved that in Poland older age has particularly significant impact on lowering the QOL, while, e.g. in Spain the significant factors resulting in a lowered QOL were depression and alcohol consumption, and in Finland - ischaemic heart disease [18]. The relationship between individual QOL and age seems controversial. Some international studies found age to be one of the most 
Table 2. Comparison of WHOQOL-Bref domains mean scores, standard deviations, and significance based on socio-demographic variables

\begin{tabular}{|c|c|c|c|c|c|c|c|}
\hline Variables & & Physical & Psychological & Social & Environment & $\begin{array}{l}\text { Q1 - subjective } \\
\text { overall quality } \\
\text { of life }\end{array}$ & $\begin{array}{l}\text { Q2 - subjective } \\
\text { general health }\end{array}$ \\
\hline & & $\begin{array}{l}\text { Mean } \\
(\mathrm{SD})\end{array}$ & $\begin{array}{l}\text { Mean } \\
(\mathrm{SD})\end{array}$ & $\begin{array}{l}\text { Mean } \\
(\mathrm{SD})\end{array}$ & $\begin{array}{l}\text { Mean } \\
(\mathrm{SD})\end{array}$ & $\begin{array}{l}\text { Mean } \\
(\mathrm{SD})\end{array}$ & $\begin{array}{l}\text { Mean } \\
\text { (SD) }\end{array}$ \\
\hline & & $r$ & $r$ & $r$ & $r$ & $r$ & $r$ \\
\hline \multirow{3}{*}{ Gender } & Female & $\begin{array}{c}57.96 \\
(14.47)\end{array}$ & $\begin{array}{c}59.81 \\
(12.63)\end{array}$ & $\begin{array}{c}66.08 \\
(17.16)\end{array}$ & $\begin{array}{c}63.20 \\
(16.10)\end{array}$ & $\begin{array}{c}3.54 \\
(0.84)\end{array}$ & $\begin{array}{c}3.32 \\
(1.05)\end{array}$ \\
\hline & Male & $\begin{array}{l}59.75 \\
(15.18)\end{array}$ & $\begin{array}{c}60.34 \\
(13.31)\end{array}$ & $\begin{array}{c}68.98 \\
(17.38)\end{array}$ & $\begin{array}{c}64.74 \\
(17.57)\end{array}$ & $\begin{array}{c}3.62 \\
(0.84)\end{array}$ & $\begin{array}{c}3.50 \\
(1.07)\end{array}$ \\
\hline & $\mathrm{p}$ & $0.070^{\text {a) }}$ & $0.472^{\text {a) }}$ & $0.012^{\mathrm{a})}$ & $0.197^{\text {a) }}$ & $0.269^{\text {a) }}$ & $0.008^{\text {a) }}$ \\
\hline \multirow{2}{*}{ Age } & & -0.39 & -0.39 & -0.30 & -0.37 & -0.26 & -0.24 \\
\hline & $\mathrm{p}$ & $<0.001^{\text {b) }}$ & $<0.001^{b)}$ & $<0.001^{\text {b) }}$ & $<0.001^{\text {b) }}$ & $<0.001^{b)}$ & $<0.001^{\text {b) }}$ \\
\hline \multirow{3}{*}{ Marital status } & In a relationship & $\begin{array}{c}60.38 \\
(15.42)\end{array}$ & $\begin{array}{c}61.74 \\
(13.05)\end{array}$ & $\begin{array}{c}69.96 \\
(17.26)\end{array}$ & $\begin{array}{c}65.78 \\
(17.51)\end{array}$ & $\begin{array}{c}3.67 \\
(0.82)\end{array}$ & $\begin{array}{c}3.53 \\
(1.04)\end{array}$ \\
\hline & Single & $\begin{array}{c}55.14 \\
(12.64)\end{array}$ & $\begin{array}{c}56.34 \\
(11.84)\end{array}$ & $\begin{array}{c}61.62 \\
(16.01)\end{array}$ & $\begin{array}{c}59.69 \\
(14.14)\end{array}$ & $\begin{array}{c}3.37 \\
(0.85)\end{array}$ & $\begin{array}{c}3.13 \\
(1.06)\end{array}$ \\
\hline & $\mathrm{p}$ & $<0.001^{\text {a) }}$ & $<0.001^{\text {a) }}$ & $<0.001^{\text {a) }}$ & $<0.001^{\text {a) }}$ & $<0.001^{\text {a) }}$ & $<0.001^{\text {a) }}$ \\
\hline \multirow{5}{*}{ Education } & Primary or lower & $\begin{array}{c}56.76 \\
(14.84)\end{array}$ & $\begin{array}{c}58.40 \\
(12.63)\end{array}$ & $\begin{array}{c}65.78 \\
(17.26)\end{array}$ & $\begin{array}{c}61.94 \\
(17.10)\end{array}$ & $\begin{array}{c}3.49 \\
(0.85)\end{array}$ & $\begin{array}{l}3.29 \\
(1.09)\end{array}$ \\
\hline & Vocational & $\begin{array}{c}61.46 \\
(15.14)\end{array}$ & $\begin{array}{c}61.50 \\
(13.51)\end{array}$ & $\begin{array}{c}68.82 \\
(18.25)\end{array}$ & $\begin{array}{c}66.34 \\
(17.29)\end{array}$ & $\begin{array}{l}3.65 \\
(0.86)\end{array}$ & $\begin{array}{c}3.52 \\
(1.11)\end{array}$ \\
\hline & Secondary & $\begin{array}{c}58.58 \\
(14.87)\end{array}$ & $\begin{array}{c}60.88 \\
(13.32)\end{array}$ & $\begin{array}{c}68.63 \\
(16.54)\end{array}$ & $\begin{array}{c}64.47 \\
(15.82)\end{array}$ & $\begin{array}{c}3.61 \\
(0.84)\end{array}$ & $\begin{array}{c}3.45 \\
(0.99)\end{array}$ \\
\hline & Higher & $\begin{array}{c}61.71 \\
(11.18)\end{array}$ & $\begin{array}{c}62.51 \\
(10.39)\end{array}$ & $\begin{array}{c}68.12 \\
(15.98)\end{array}$ & $\begin{array}{c}65.31 \\
(14.34)\end{array}$ & $\begin{array}{l}3.77 \\
(0.67)\end{array}$ & $\begin{array}{l}3.53 \\
(0.90)\end{array}$ \\
\hline & $\mathrm{p}$ & $<0.001^{c)}$ & $0.001^{c)}$ & $0.006^{c)}$ & $0.001^{c)}$ & $0.003^{c)}$ & $0.010^{c)}$ \\
\hline \multirow{3}{*}{$\begin{array}{l}\text { Physical activity performed } \\
\text { daily, a minimum of } 150 \\
\text { minutes per week }\end{array}$} & No & $\begin{array}{c}56.95 \\
(14.44) \\
\end{array}$ & $\begin{array}{c}59.27 \\
(12.68) \\
\end{array}$ & $\begin{array}{c}66.02 \\
(16.86) \\
\end{array}$ & $\begin{array}{c}62.15 \\
(15.84) \\
\end{array}$ & $\begin{array}{r}3.49 \\
(0.85) \\
\end{array}$ & $\begin{array}{r}3.29 \\
(1.07) \\
\end{array}$ \\
\hline & Yes & $\begin{array}{c}62.65 \\
(14.84)\end{array}$ & $\begin{array}{c}61.73 \\
(13.30)\end{array}$ & $\begin{array}{c}70.24 \\
(17.92)\end{array}$ & $\begin{array}{c}67.62 \\
(18.08)\end{array}$ & $\begin{array}{c}3.77 \\
(0.79)\end{array}$ & $\begin{array}{c}3.64 \\
(1.00)\end{array}$ \\
\hline & $\mathrm{p}$ & $<0.001^{\text {a) }}$ & $0.007^{\text {a) }}$ & $0.005^{\text {a) }}$ & $<0.001^{\text {a) }}$ & $<0.001^{\text {a) }}$ & $<0.001^{\text {a) }}$ \\
\hline \multirow{4}{*}{$\begin{array}{l}\text { Physical exercises performed } \\
\text { to strengthen muscles } \\
\text { and improve physical } \\
\text { performance per week }\end{array}$} & No & $\begin{array}{c}58.67 \\
(14.91)\end{array}$ & $\begin{array}{c}59.45 \\
(13.16)\end{array}$ & $\begin{array}{c}66.88 \\
(17.96)\end{array}$ & $\begin{array}{c}63.04 \\
(17.28)\end{array}$ & $\begin{array}{c}3.55 \\
(0.86)\end{array}$ & $\begin{array}{c}3.38 \\
(1.08)\end{array}$ \\
\hline & $1-3$ times & $\begin{array}{c}59.43 \\
(14.58)\end{array}$ & $\begin{array}{c}62.27 \\
(12.08)\end{array}$ & $\begin{array}{c}70.45 \\
(15.21)\end{array}$ & $\begin{array}{c}67.04 \\
(15.03)\end{array}$ & $\begin{array}{c}3.62 \\
(0.73)\end{array}$ & $\begin{array}{c}3.55 \\
(0.93)\end{array}$ \\
\hline & 4 and more times & $\begin{array}{c}58.53 \\
(14.18)\end{array}$ & $\begin{array}{c}62.83 \\
(11.12)\end{array}$ & $\begin{array}{c}67.97 \\
(12.75)\end{array}$ & $\begin{array}{c}67.60 \\
(12.72)\end{array}$ & $\begin{array}{c}3.70 \\
(0.76)\end{array}$ & $\begin{array}{c}3.42 \\
(1.00)\end{array}$ \\
\hline & $p$ & $0.604^{c)}$ & $0.002^{c)}$ & $0.042^{\mathrm{c})}$ & $<0.001^{\mathrm{c})}$ & $0.239^{c)}$ & $0.266^{c)}$ \\
\hline \multirow{3}{*}{$\begin{array}{l}\text { Membership in at least } \\
\text { one organization/group/ } \\
\text { association (social activity) }\end{array}$} & No & $\begin{array}{c}58.82 \\
(15.17)\end{array}$ & $\begin{array}{c}59.30 \\
(13.04)\end{array}$ & $\begin{array}{c}67.00 \\
(17.69)\end{array}$ & $\begin{array}{c}63.58 \\
(17.48)\end{array}$ & $\begin{array}{c}3.57 \\
(0.86)\end{array}$ & $\begin{array}{c}3.41 \\
(1.08)\end{array}$ \\
\hline & Yes & $\begin{array}{c}58.43 \\
(13.29)\end{array}$ & $\begin{array}{c}62.95 \\
(12.05)\end{array}$ & $\begin{array}{c}68.69 \\
(15.71)\end{array}$ & $\begin{array}{c}64.99 \\
(13.59)\end{array}$ & $\begin{array}{c}3.61 \\
(0.73)\end{array}$ & $\begin{array}{c}3.37 \\
(1.01)\end{array}$ \\
\hline & $p$ & $0.897^{\text {a) }}$ & $0.009^{\mathrm{a})}$ & $0.075^{\text {a) }}$ & $0.031^{\text {a) }}$ & $0.498^{\mathrm{a})}$ & $0.621^{\text {a) }}$ \\
\hline \multirow{2}{*}{ Number of chronic diseases } & & -0.49 & -0.20 & -0.22 & -0.30 & -0.35 & -0.48 \\
\hline & $\mathrm{p}$ & $<0.001^{\text {b) }}$ & $<0.001^{\text {b) }}$ & $<0.001^{\text {b) }}$ & $<0.001^{\text {b) }}$ & $<0.001^{\text {b) }}$ & $<0.001^{\text {b) }}$ \\
\hline
\end{tabular}

a) Mann-Whitney U test

b) significance test for linear correlation coefficient

c) Kruskal-Wallis test 
Table 3. Multiple linear regression analysis

\begin{tabular}{|c|c|c|c|c|c|c|}
\hline \multirow[t]{2}{*}{ WHOQOL-Bref domains } & \multirow[t]{2}{*}{ Variables } & \multicolumn{2}{|c|}{$\begin{array}{l}\text { Unstandardized } \\
\text { coefficients }\end{array}$} & \multirow{2}{*}{$\begin{array}{c}\begin{array}{c}\text { Standardized } \\
\text { coefficients }\end{array} \\
\text { Beta }\end{array}$} & \multirow[t]{2}{*}{$\mathrm{t}$} & \multirow[t]{2}{*}{$\mathrm{p}$} \\
\hline & & B & SE & & & \\
\hline & Number of chronic diseases & -1.715 & 0.115 & -0.405 & -14.920 & $<0.001$ \\
\hline & Physical activity $\geq 150 \mathrm{~min} /$ week $^{\text {a) }}$ & 1.760 & 0.421 & 0.111 & 4.184 & $<0.001$ \\
\hline & Marital status - in a relationship b) & 0.934 & 0.435 & 0.059 & 2.149 & 0.032 \\
\hline & Vocational education c) & 0.985 & 0.718 & 0.055 & 1.373 & 0.170 \\
\hline & Secondary education c) & -1.330 & 0.760 & -0.070 & -1.750 & 0.080 \\
\hline & Higher education c) & 0.095 & 1.090 & 0.004 & 0.087 & 0.931 \\
\hline \multirow[t]{9}{*}{ Psychological } & Age & -0.678 & 0.068 & -0.321 & -9.955 & $<0.001$ \\
\hline & Number of chronic diseases & -0.483 & 0.113 & -0.131 & -4.286 & $<0.001$ \\
\hline & Physical activity $\geq 150 \mathrm{~min} /$ week $^{\text {a) }}$ & 0.570 & 0.409 & 0.041 & 1.392 & 0.164 \\
\hline & Performing physical exercises 4 or more times d) & 1.959 & 0.932 & 0.094 & 2.101 & 0.036 \\
\hline & Social activity ${ }^{\mathrm{e})}$ & 1.533 & 0.478 & 0.096 & 3.210 & 0.001 \\
\hline & Marital status - in a relationship ${ }^{\text {b) }}$ & 1.465 & 0.424 & 0.105 & 3.456 & 0.001 \\
\hline & Vocational education c) & 0.214 & 0.694 & 0.014 & 0.309 & 0.758 \\
\hline & Secondary education c) & -0.494 & 0.737 & -0.030 & -0.670 & 0.503 \\
\hline & Higher education c) & -0.049 & 1.059 & -0.002 & -0.047 & 0.963 \\
\hline \multirow[t]{5}{*}{ Social } & Age & -0.613 & 0.090 & -0.217 & -6.803 & $<0.001$ \\
\hline & Number of chronic diseases & -0.713 & 0.154 & -0.144 & -4.616 & $<0.001$ \\
\hline & Gender ${ }^{f}$ & 0.115 & 0.559 & 0.007 & 0.205 & 0.838 \\
\hline & Physical activity $\geq 150 \mathrm{~min} /$ week $^{\text {a) }}$ & 1.423 & 0.562 & 0.076 & 2.535 & 0.011 \\
\hline & Marital status - in a relationship ${ }^{\text {b) }}$ & 2.879 & 0.614 & 0.154 & 4.693 & $<0.001$ \\
\hline \multirow[t]{8}{*}{ Environment } & Age & -0.805 & 0.087 & -0.294 & -9.281 & $<0.001$ \\
\hline & Physical activity $\geq 150 \mathrm{~min} /$ week $^{\text {a) }}$ & 1.700 & 0.525 & 0.094 & 3.239 & 0.001 \\
\hline & Performing physical exercises $1-3$ times ${ }^{\text {d) }}$ & 0.586 & 1.150 & 0.023 & 0.510 & 0.610 \\
\hline & Performing physical exercises 4 or more times ${ }^{d)}$ & 2.377 & 1.195 & 0.088 & 1.989 & 0.047 \\
\hline & Marital status - in a relationship ${ }^{\text {b) }}$ & 1.225 & 0.540 & 0.068 & 2.271 & 0.023 \\
\hline & Vocational education $^{\mathrm{c})}$ & 1.156 & 0.891 & 0.056 & 1.298 & 0.195 \\
\hline & Secondary education ${ }^{\mathrm{c})}$ & -0.632 & 0.945 & -0.029 & -0.669 & 0.504 \\
\hline & Higher education ${ }^{c}$ & -1.331 & 1.357 & -0.050 & -0.981 & 0.327 \\
\hline \multirow{7}{*}{$\begin{array}{l}\text { Q1 - subjective overall } \\
\text { quality of life }\end{array}$} & Age & -0.022 & 0.004 & -0.160 & -4.985 & $<0.001$ \\
\hline & Number of chronic diseases & -0.070 & 0.007 & -0.292 & -9.631 & $<0.001$ \\
\hline & Physical activity $\geq 150 \mathrm{~min} /$ week $^{\text {a) }}$ & 0.099 & 0.027 & 0.109 & 3.709 & $<0.001$ \\
\hline & Marital status - in a relationship ${ }^{\text {b) }}$ & 0.085 & 0.027 & 0.094 & 3.108 & 0.002 \\
\hline & Vocational education c) & -0.014 & 0.045 & -0.014 & -0.312 & 0.755 \\
\hline & Secondary education ${ }^{\mathrm{c})}$ & -0.039 & 0.048 & -0.037 & -0.821 & 0.412 \\
\hline & Higher education c) & 0.073 & 0.069 & 0.054 & 1.058 & 0.290 \\
\hline \multirow{8}{*}{$\begin{array}{l}\text { Q2 - subjective general } \\
\text { health }\end{array}$} & Age & -0.017 & 0.005 & -0.098 & -3.211 & 0.001 \\
\hline & Number of chronic diseases & -0.133 & 0.009 & -0.436 & -15.083 & $<0.001$ \\
\hline & Gender $^{f)}$ & 0.035 & 0.032 & 0.032 & 1.091 & 0.276 \\
\hline & Physical activity $\geq 150 \mathrm{~min} /$ week $^{\text {a) }}$ & 0.100 & 0.032 & 0.087 & 3.130 & 0.002 \\
\hline & Marital status - in a relationship ${ }^{\text {b) }}$ & 0.139 & 0.035 & 0.121 & 3.974 & $<0.001$ \\
\hline & Vocational education c) & 0.021 & 0.055 & 0.016 & 0.387 & 0.699 \\
\hline & Secondary education ${ }^{\mathrm{c})}$ & -0.009 & 0.058 & -0.006 & -0.153 & 0.879 \\
\hline & Higher education c) & 0.000 & 0.083 & 0.000 & 0.004 & 0.997 \\
\hline
\end{tabular}

a) in reference to respondents, whose physical activity $<150 \mathrm{~min} /$ week

b) in reference to single respondents

c) in reference to respondents with primary or lower education

d) in reference to respondents who did not perform physical exercises

e) in reference to respondents socially inactive

f) in reference to men

${ }^{*} \mathrm{~B}$ - regression intercept; SE - standard error; BETA - standardized regression intercept; $\mathrm{t}$ - the value of test statistic of regression intercept; $\mathrm{p}$ - test probability. 
significant predicators of lowered QOL, most likely because it is related to chronic diseases of older adults $[19,20]$. Other studies have not confirmed this relationship [21,22].

Chronic diseases significantly lower the QOL of older adults. Most chronic diseases are related to problems related to mobility, and basic and instrumental activities of daily living. The longer an elderly person is immobile, the higher the chance of developing long term disability, and the poorer their chance to regain the ability to live independently. This is related to a low level of adaptation of an elderly body [23]. Other studies stressed the burden of heath related problems and pain on lowered quality of life of older adults [18]. Analysis of regression by Kumar et al. showed a significant impact of musculoskeletal disorders $(\mathrm{p} \leq 0.001)$, poor eyesight $(\mathrm{p}=0.049)$ and hearing impairment $(\mathrm{p}=0.001)$ on $\mathrm{QOL}$ [17]. QOL is essential for patients with chronic diseases, as problems with their diseases have an impact on certain areas of their lives [24]. Studies by numerous authors confirm lowered QOL with a number of chronic diseases [25-27].

In the current study it was found that older adults who were in a relationship were more likely to have a high QOL than single respondents. Analysis of regression by Kumar et al. found a significant impact of relationships on QOL. In their study, single respondents had a significantly lower QOL than those in relationships $(\mathrm{p}=0.001)$ [17].

The current study also showed that the loneliness of older adults is a very important factor resulting in a lowered QOL. Taube et al. confirmed this observation. They studied the experience of loneliness of elderly subjects living independently at home, and found that this was dangerous for their physical and psychological well being [28]. The lonely life of older adults results in their declined social participation. The environmental factor of being able to use other people's help on everyday basis is essential in maintaining the ability to perform both the simple and complex activities of daily life [29], and in the improvement of the QOL of older adults $[30,31]$. Ishikawa et al. proved that factors strongly related to low subjective well-being were difficulties experienced when shopping $(\mathrm{p}<0.0001)$, lack of anyone who could help by shopping for food $(\mathrm{p}=0.043)$, lack of anyone who could prepare breakfast $(\mathrm{p}=0.001)$, and rare occasions on which to eat meals with another person $(p=0.002)$ [32]. Loneliness increases with diminishing social contacts of older adults. It was found that frequent contacts and visits from friends and family motivate activity and increase the QOL [33].

The presented study found that increase in physical activity significantly improved the QOL of older adults. Gill et al. found that a higher level of physical activity determines the QOL [34] and acts as its protective factor [35]. Interventions aimed at increased activity of older adults affect their QOL positively. Dumitrache et al. conducted a study involving a nine-month long intervention. It had three weekly workshops lasting, on average, four hours, which stimulated cognitive abilities, crafts and physical activity. The authors found that regardless of age, education, gender and initial test results, the members of the intervention group had lower risk of distortions in cognitive functions. They also maintained these results in the psychological domain of the WHOQOLBref, while the clinical controls had slightly decreased results. The intervention programme had a positive impact on the perception of its participants in relation to their abilities to participate in recreation activities, and improvement of their cognitive functioning which, in turn, contributed to their more positive perception of their own mental health [36].

\section{CONCLUSION}

The problem of ageing and the quality of life of the rural inhabitants of Poland in relation to a number of factors still require further studies, as each group has their own characteristic features which may have been omitted in standard analysis. The authors of this study believe that such studies may contribute to the formulation of new policies in public health and long term social care for older adults. Older adults should be able to benefit from interdisciplinary monitoring aimed at promoting health, improving activity and everyday life participation of older adults.

The current study stresses the impact of modifiable determiners of QOL and provides conclusions on public health that could support specific actions nationwide. In particular, an increase in physical activity and strengthening of social networks may potentially increase the quality of life of the ageing population [18].

\section{REFERENCES}

1. Population structure and ageing. Eurostat. http://ec.europa.eu/eurostat/ statistics-explained/index.php/Population_structure_and_ageing. (access: 2018.02.20).

2. Preventing chronic diseases: a vital investment. http://www.who.int/ chp/chronic_disease_report/en/. (access: 2018.02.24).

3. Ola M, Mathur R. Various environmental factors and their impact on subjective well-being on the older adults. Indian J Health Wellbeing. 2018; 9(1): 89-92.

4. Gobbens R. Associations of Environmental Factors With Quality of Life in Older Adults. Gerontol. 2018; 58(1): 101-110.

5. Pedersen M, Vorup J, Bangsbo J, Wikman JM, Alstrøm JM, Melcher PS, et al. Effect of team sports and resistance training on physical function, quality of life, and motivation in older adults. Scand J Med Sci Sports. 2017; 27(8): 852-864.

6. Guler N, Guler Z, Özel D. Ageing in the rural area:quality of life and associated factors in Sivas/Turkey. Turkish J Geriatr. 2016; 19(4): 245-252.

7. Kritika, Kakkar R, Aggarwal P, Semwal J. Quality of Life (QOL) among the Elderly in Rural Dehradun. Indian J Com Health. 2017; 29(1): 39-45.

8. Höfelmann D, Gonzalez-Chica D, Peres K, Boing AF, Peres MA. Chronic diseases and socioeconomic inequalities in quality of life among Brazilian adults: findings from a population-based study in Southern Brazil. Eur J Public Health. 2017; doi: 10.1093/eurpub/ckx224.

9. Mossakowska M, Więcek A, Błędowski P. Aspekty medyczne, psychologiczne, socjologiczne i ekonomiczne starzenia się ludzi w Polsce, część III. Termedia Wydawnictwa Medyczne, 2012.

10. Skevington SM, Lotfy M, WHOQOL Group.. The World Health Organization's WHOQOL-BREF quality of life assessment: psychometric properties and results of the international field trial. A report from the WHOQOL group. Qual Life Res. 2004; 13(2): 299-310.

11. Soósová MS. Determinants of quality of life in the elderly. Cent Eur J Nurs Midw. 2016; 7: 484-493.

12. Trentini C, Wagner G, Fleck M, Figueiredo M, da Silva L, Hirakata V, et al. Subjective perception of health in elderly inpatients. Int J Psychol. 2012; 47(4): 279-286.

13. Milanović Z, Pantelić S, Trajković N, Sporiš G, Kostić R, James N. Age-related decrease in physical activity and functional fitness among elderly men and women. Clin Interv Aging. 2013; 8: 549-56.

14. Klima E, Janiszewska A, Mordwa S. Elderly people and their quality of life - challenges for geography. In: Klima E, editor. Population, Housing, Services - 70th Anniversary of Professor Jerzy Dzieciuchowicz, „SpaceSociety-Economy" 13, Department of Population and Services Studies, Wydawnictwo Uniwersytetu Łódzkiego; Łódź. p173-189.

15. Borowiak E, Kostka T. Predictors of quality of life in older people living at home and in institutions. Aging Clin Exp Res. 2004; 16(3): 212-20.

16. Population Aging in Europe. European Commission. https://www. google.com/url? sa $=$ t\&rct $=j \& q=\& e s r c=s \&$ source $=$ web $\& c d=1 \& c a d=r$ 
ja\&uact $=8 \&$ ved $=0$ ahUKEwjDosTSi7bcAhUIiCwKHV8PBokQFggu MAA\&url=https\%3A\%2F\%2Fec.europa.eu\%2Fresearch\%2Fsocialsciences\%2Fpdf\%2Fpolicy_reviews\%2Fkina26426enc.pdf\&usg=AO vVaw0yTvr9dKNR811xzTFUxcfz. (access: 2018.07.20).

17. Kumar S, Majumdar A, Pavithra G. Quality of Life (QOL) and Its Associated Factors Using WHOQOL-BREF Among Elderly in Urban Puducherry, India. J Clin Diagn Res. 2014; 8(1): 54-57.

18. Raggi A, Corso B, Minicuci N, Quintas R, Sattin D, De Torres L, et al Determinants of Quality of Life in Ageing Populations: Results from a Cross-Sectional Study in Finland, Poland and Spain. PLoS ONE. 2016; 11(7): e0159293.

19. Parker L, Moran G, Roberts L, Calvert M, McCahon D. The burden of common chronic disease on health-related quality of life in an elderly community-dwelling population in the UK. Fam Pract. 2014; 31(5): $557-563$.

20. Hunger M, Thorand B, Schunk M, Döring A, Menn P, Peters A, et al. Multimorbidity and health-related quality of life in the older population: results from the German KORA-age study. Health Qual Life Outcomes. 2011; 9: 53.

21. Garin N, Olaya B, Haro J, Miret M, Lobo A, Ayuso-Mateos JL, et al. Impact of multimorbidity on disability and quality of life in the Spanish older population. Plos One. 2014; 9(11): el11498.

22. Low G, Molzahn A, Schopflocher D. Attitudes to aging mediate the relationship between older peoples' subjective health and quality of life in 20 countries. Health Qual Life Outcomes. 2013; 11: 146.

23. Provencher V, Carbonneau H, Filion-Trudeau M, Puolin J, Filiatrault D, Giroux D, et al. Exploring the Impact of a New Intervention to Increase Participation of Frail Older Adults in Meaningful Leisure Activities. Activ Adap Aging. 2018; 42(1): 1.

24. Tóthová V, Bártlová S, Olišarová V, Kaas J, Kimmer D, Maňhalová J, et al. Quality of life in patients with chronic diseases. Neuro Endocrinol Letters. 2014; 35: 11-18.

25. Campos A, Ferreira E, Vargas A, Albala C. Aging, Gender and Quality of Life (AGEQOL) study: factors associated with good quality of life in older Brazilian community-dwelling adults. Health Qual Life Outcomes. 2014; 12: 166.
26. Bottan G, Morais E, Schneider J, Trentini C, Heldt E. Determinants of quality of life in elderly patients of a psychosocial care center in Brazil. Issues Ment Health Nurs. 2014; 35(3): 181-188.

27. Pan C, Cong X, Wang P, Wang XZ, Sun HP, Xu Y, et al. Evaluating health-related quality of life impact of chronic conditions among older adults from a rural town in Suzhou, China. Arch Gerontol Geriatr. 2018; 76: 6-11.

28. Taube E, Jakobsson U, Midlöv P, Kristensson J. Being in a bubble: the experience of loneliness among frail older people. J Adv Nurs. 2015; 72: 631-640.

29. Ćwirlej-Sozańska A, Sozański B, Wiśniowska-Szurlej A, WilmowskaPieturuszyńka A. An assessment of factors related to disability in ADL and IADL in elderly inhabitants of rural areas of south-eastern Poland. Ann Agr Env Med. 2018; doi: 10.26444/aaem/81311.

30. Tamai S, Paschoal S, Jacob-Filho W, Machado, Curiati P, Prada L, et al. Impact of a program to promote health and quality of life of elderly. Einstein. 2011; 9(1): 8-13.

31. Araújo A, Rebouças Barbosa R, de Medeiros II, de Araújo RF Jr, de Medeiros CA. Quality of Life, Family Support, and Comorbidities in Institutionalized Elders With and Without Symptoms of Depression. Psychiatr Q. 2016; 87(2): 281-2.

32. Ishikawa M, Yokoyama T, Murayama N, Takemi Y, Nakaya T, Fukuda Y, et al. Subjective Well-Being Is Associated with Food Behavior and Demographic Factors in Chronically Ill Older Japanese People Living Alone. J Nutr Health Aging. 2018; 22(3): 341-353.

33. Noro A, Aro S. Health-related quality of life among the least dependent institutional elderly compared with the non-institutional elderly population. Qual Life Res. 1996; 5: 355-366.

34. Gill DL, Hammond CC, Reifsteck EJ, Jehu CM, Williams RA, Adams MM, et al. Physical activity and quality of life. J Prev Med Public Health. 2013; 46: 28-34.

35. Sampaio PY, Ito E. Activities with higher influence on quality of life in older adults in Japan. Occup Ther Int. 2013; 20: 1-10.

36. Dumitrache CG, Rubio L, Bedoya I, Rubio Herra R. Promoting Active Aging in rural Settings: an Intervention Program Implemented in Orense, Spain. Univers Psychol. 2017; 16(3): 1-12. 